\title{
NAMES OF PLANTS IN THE RUSSIAN AND CHINESE LINGUISTIC PICTURE OF THE WORLD (BASED ON PROVERBS OF THE RUSSIAN AND CHINESE LANGUAGES)
}

\author{
Wu Luqian ${ }^{1}$, Alena Ju. Nikitina ${ }^{2^{*}}$, Olga A. Petrova ${ }^{3}$ \\ ${ }^{1}$ Lecturer, Provisional Head of the Russian Department of School of Foreign Studies, Anhui \\ University, CHINA, 827374420@qq.com, \\ ${ }^{2}$ Assoc. Prof., Chuvash State University, RUSSIA, alyona.nikitina@gmail.com \\ ${ }^{3}$ Assoc. Prof., Chuvash State University, RUSSIA, zadumka@mail.ru \\ ${ }^{*}$ Corresponding Author
}

\begin{abstract}
The article presents the results of a comparative linguoculturological analysis of linguistic units representing the "plant" cluster in the Russian and Chinese linguistic world-image. The object of the research is proverbs with a phytonym component (with the names of trees and plants and their fruits). The relevance of this study is justified by the fact that the study and comparison of linguistic world-image of different peoples is a developing direction in linguistics because the worldview and attitude of the people, their own version of the image of the world are fixed in the semantics of words. The aim of the research is to analyze the proverbs with names of plants of the Russian and Chinese languages and to describe the features of the Russian and Chinese linguistic world-image through the prism of linguocultural studies. Since plants have been present in the life of any nation since antiquity and are an integral part of human life, it is not surprising that phytonyms are often found in phraseological units, in particular, proverbs. Phytonym components have an extremely wide associative potential, vividly reflect the peculiarities of national consciousness and the specifics of the linguistic world-image of the people as a whole; they can be international and nationally specific. The research showed that in the Russian and Chinese languages, proverbs containing components of plant names can be divided into 3 groups: 1) proverbs with a tree component (fruit and non-fruit);2) proverbs with a cultivated plant component; 3 ) proverbs with an uncultivated (wild) plant component. The analysis showed that in the Russian and Chinese languages the absolute majority belongs to proverbs with a tree component, both fruit and non-fruit. The study also revealed that from a semantic point of view, a significant number of proverbs with components of plant names describe a person's character, his external and physical data, moral qualities. Semantic analysis of proverbs showed that sayings with the names of plants can have a similar image and be used in the same meaning in the languages under consideration, or they can have completely different connotations, which are due to the national specifics of culture, lifestyle, imaginative perception of the external world by both peoples.
\end{abstract}

Keywords: connotation, linguistic and cultural studies, linguistic world-image, proverbs, phytonyms.

\section{INTRODUCTION}

In modern linguistics, an actual direction of research is the study of language from the point of view of its relationship with material and mental reality, as a reflection of the specific way of perceiving the world and realities both by an individual and by a certain people. In this regard, the object of close attention of modern linguists is the description of the linguistic world-image.

At present, the concept "linguistic world-image" is at the stage of active study: linguists are making attempts 
to formulate its full and detailed definition, to differentiate it from other related concepts. In science, there is no single approach to the definition of this term. V. A. Maslova notes that along with the most frequently used notion "linguistic world-image", various linguists use such definitions as "linguistic intermediate world", "linguistic representation of the world", "linguistic model of the world", etc. (Maslova, 2001, p. 63). And V.A. Maslova gives her own definition too: the linguistic world-image is a set of all human knowledge about the world, captured in linguistic form (Maslova, 2001, p. 63). N. Yu. Shvedova emphasizes that "a world-image is a picture of everything that exists as an integral and multifaceted world in its structure and in the connections of its parts, which is comprehended by the language of its parts, developed by the centuries-old experience of the people and carried out by means of linguistic nominations. Firstly, a person, his material and spiritual life activity and, secondly, everything that surrounds him: space and time, living and inanimate nature, the area of myths created by man and society" (Shvedova, 1999, p. 14). Therefore, people's culture, way of life, beliefs and religious views are reflected in the linguistic world-image of the people.

The relevance of this study is justified by the fact that the study and comparison of linguistic world-image of different peoples is a developing direction in linguistics due to the fact that "the worldview and attitude of the people, their own version of the image of the world, are fixed in the semantics of words" (Borisova, 2018, p. $66)$.

This article presents the results of a comparative linguocultural study of proverbs, including the names of plants that play an important role in the Russian and Chinese linguistic world-image. In the Chinese language, the Russian concept of the proverb corresponds to the word yanyu (读语 - proverb), which is also distinguished by an instructive and didactic character and in which the experience and life wisdom of the Chinese people, its mentality and world-image are reflected.

\section{METHODOLOGY}

Research methods are conditioned by the set goals and objectives. The main method is comparativetypological, which allows to identify the general and differences in the use of plant names in the Russian and Chinese world-image. Descriptive and contextual methods have been used to interpret the meaning given by representatives of two nationalities to proverbs containing a plant component. The method of continuous sampling was used when working with the phraseological fund of the Russian and Chinese languages.

\section{RESULTS}

Russian and Chinese proverbs often include the names of various trees, herbs and flowers, cultivated and wild plants, etc. In this regard, proverbs can be divided into 3 groups: 1) proverbs with a tree component (fruit and non-fruit); 2) proverbs with a cultivated plant component; 3) proverbs with an uncultivated (wild) plant component.

\subsection{Proverbs with a Tree Component}

Proverbs with a tree component (fruit and non-fruit) are the most common in the Russian and Chinese languages. The analysis of the material showed that in Russian proverbs such fruit trees as pear and apple are more common, in Chinese there are pear, peach, and plum; among barren trees there are oak, birch, aspen, willow and pine (in Russian proverbial expressions), willow and pine (in Chinese).

First of all, it should be noted the volume of the meaning of the lexeme tree in the Russian and Chinese languages is different. In the Explanatory Dictionary of S. I. Ozhegov the following definition is given: a tree is 'a perennial plant with a hard trunk and branches extending from it, forming a crown' (Ozhegov). The Xinhua Dictionary gives the following interpretation of the hieroglyph 树 (tree): 1 . The general name of trees. 2. 树 大根深 - a large tree with a deep root. Also it is given figuratively meaning - smb. who has power and solid foundation (Xinhua Dictionary). Moreover, in Chinese, shrubs can also be called a tree. Therefore, the important meanings of the word tree in Russian are the trunk and branches, and in Chinese - the root and height.

The following associations and ideas about trees are common in the linguistic world-image of Russians and Chinese:

1) A job, the results of which will not be visible immediately (Деревья скоро садят, да не скоро с них плоды едят (Trees are planted soon, but they will give fruits not soon) / 砍柴上山, 捉鸟上树 (To cut brushwood you need to climb a mountain, to catch a bird you need to climb a tree));

2) Parents and children (От доброго дерева добрый и плод (From a nice tree, you will have nice fruit / 哪样 
树开哪样花 (A flower will look like a tree));

3) Cause-and-effect relationship (Не от добра дерево листья роняет (A tree drops leaves not because of good reason) / 树不坚硬虫来咬 (If the tree is not solid, worms like to eat it));

4) Assessment of human qualities (Дерево познается по плодам, а человек по делам (A tree is known by its fruits, and a person by deeds) / 树正不怕月影斜 (A straight tree is not afraid of the curve of the moon's shadow)).

It should be noted that both in Russian proverbs and in Chinese, the root of a tree is especially prominent as the basis, an important component of both plants and the foundations of humanity: Дерево держится корнями, а человек - друзьями (A tree is kept by its roots, and a person is kept by friends) / 树从根上起 (The tree grows from its root), 树长根, 人长心 (A tree grows a root, a person grows a soul).

Nevertheless, differences can be traced in the world-image of the Russians and the Chinese. So, in Russian, a tree also has associations with friendship (Человек без друзей, что дерево без корней (A man without friends is like a tree without roots), with the upbringing of the young generation (Гни дерево, пока гнётся, учи дитятко, пока слушается (Rot a tree while it is bending, teach a child while he is listening)), and in Chinese - with spiritual origins (树从根上起 (A tree grows from its root), 树要皮, 人要脸 (A person needs a face, a tree needs bark (it says about the importance of reputation for a person; a person needs to preserve honor as much as a tree needs bark); 树长根, 人长心 (A tree grows a root, a person grows a soul (if a tree grows a root, it can become thick; if a person has a conscience, he has morality)).

The most revered barren trees in Russian culture are an oak, a birch, a pine. Thus, the oak in proverbs acts as a symbol of strength, spiritual and physical strength: Не срубишь дуба, не отдув губы (You cannot cut down an oak without blowing your lips off); Держись за дубок, дубок в землю глубок (Hold on to the oak, the oak is deep in the ground). In the Russian world-image the birch is associated with girlish beauty, and is also often used to characterize a person: Кривая береза не удержит снега, плохой человек не сдержит слова (A crooked birch will not hold snow, a bad person will not keep his word), Горбатую березу распаришь да поправишь, а дурного человека хоть парь, хоть май - всё таким останется (You can steam a humpbacked birch and fix it, but you can steam and excruciate a bad person - but he will remain the same).

Vivid phytonyms reflecting the peculiarities of the Chinese national world-image are trees such as pine (松 树 sōngshù), which is associated with such human qualities as nobility, unyielding will, longevity (不学杨柳随风 摆, 要学青松立山冈 (Don't learn from the poplar and willow that sway in the wind, but learn from the green pine tree on the hill)); and bamboo (竹子 zhúzi) - righteousness, honesty, integrity, unselfishness, decency, honor, will, strong spirit. However, bamboo also has a negative connotation: 竹子开花兆灾 (If bamboo blossoms, wait smth unhappy).

In Chinese proverbs, the acacia tree is often found, which has a negative connotation: 刺槐做的棒槌一扎手 (A rolling pin made of acacia wood is pricked) (the proverb is used when talking about difficult matters); 指桑 树, 骂槐树 (To point to the mulberry tree, and to scold the acacia ("to speak in roundabout, hints, not bluntly")).

Proverbs with a component of the name of a fruit tree are closely interconnected with the geographical characteristics of the peoples living, as well as ideas about the characteristics of useful property of the tree and its fruit.

The pear tree among the Russians was endowed with signs of holiness and purity, and among the Chinese it was a symbol of longevity.

Both in Chinese and in Russian, a pear can be associated with a feeling of love (Любит, как душу, трясет, как грушу (He loves like a soul, shakes like a pear)). Nevertheless, this component most often occurs when Russians talk about unreal events (Когда на сосне груши будут (When there will be pears on a pine tree)), as well as about the value of certain phenomena or things (На грушу лезть - или грушу рвать, или платье драть (To climb on a pear - or to tear a pear, or to tear a dress)); in Chinese, it is about the importance of gaining one's own life experience (百闻不如一见, 百见不如一干 (You go into the water yourself - you will find out if it is deep or shallow; if you try a pear yourself, you will know if it is sour or sweet.)

The apple-tree component is very common in Russian proverbs, however, it is practically not found in Chinese proverbs. In the Russian linguistic world-image, an apple tree is used to depict the continuity of 
generations, the similarity of parents and children (Какова яблонька, таковы и яблочки (Аpples are look like the apple tree), Яблоко от яблони недалеко падает (An apple does not fall far from an apple tree)), tracing causal relationships (От яблони яблоко родится, а от ёлки - шишка (An apple is born from an apple tree, and a pine cone from a tree)) etc. In the Chinese world-image, peach trees are used with similar meanings, associated with longevity, spiritual purity, and plum as a characteristic of the best qualities of a person (千朵桃花一树儿生 (A thousand peach flowers are born from one tree)).

\subsection{Proverbs with a Cultivated Plant Component}

In Russian and Chinese proverbs, among the names of cultivated plants and their fruits the following are most often used: wheat, carrot, radish, pumpkin, peas, beans, etc.

Among the names of cereal plants in the Russian linguistic world-image, wheat is characterized by a pronounced cultural connotation (Borisova, 2018, p. 66). The wheat component in Russian proverbs is a symbol of prosperity, which is due to the fact that in the life of the Slavs bread has always remained the main food on the table: В поле пшеница годом родится, а добрый человек всегда пригодится (In the field, wheat will be born every year, and a kind person will always be useful); Удобришь землицу - снимешь пшеницу (Fertilize the land, and you will get the wheat). Such proverbs are instructive in nature and use to characterize a person. On the contrary, in the Chinese language the phytonym wheat is found in proverbial expressions containing an assessment of the actions and life of a person: 麦高于禾, 风必吹之 (If the wheat grass grows higher than other seedlings, then the wind shakes it (about the problems arising because of the fame of a person)).

The phytonym cabbage is also used in Russian proverbs to mean wealth in the house: Ни один рот без капусты не живет (Not a single mouth can live without cabbage); Вырастишь капусту - в закромах не будет пусто (If you grow cabbage, the bins will not be empty). In Chinese, the phytonym cabbage is used for characterizing a person: 夢卜青菜, 各有所爱 (One loves radish, the other - cabbage (meaning - tastes differ).

Among leguminous plants in the Russian and Chinese linguistic world-image, peas and beans are characterized by cultural connotations. Peas in Russian proverbs has the following associations: 1) peas // something desired (Завидны в поле горох да репа: кто ни пройдёт, щипнёт (Рeas and turnips are enviable in the field: whoever passes, pinches)); 2) peas // girl (Девица в красе — что горох на полосе: кто идёт, тот щипнёт (A girl in beauty is like peas on a strip: whoever walks, he pinches)); 3) peas // harmless, defenseless person (Наш горох никому не ворог (Our peas is not an enemy to anyone)) (Borisova, 2018, p. 69). There are also proverbs in which there is a negative connotation: С твоим умом только в горохе сидеть (You should only sit in peas with your mind); Торчит меж людей, как пугало в горохе (It sticks out between people like a scarecrow in a pea). In Chinese proverbs, on the contrary, peas have positive semantics, for example, they are used to characterize a sincere, frank person: 竹筒倒豆子 (To pour peas out of a bamboo pipe).

In Russian and Chinese proverbs, carrot can be used to characterize a person (Рожа - хоть репу сей, хоть морковь сажай (Face is like to seed turnip, even plant carrots; 一个萝卜一个坑 (Each carrot has its own hole (1) one person - one place, there are no extra places for him; 2) each his own place; 3) about a person's compliance with his position or about a solid, conscientious style of work). Also carrot is used to describe social phenomena (Лук с морковкой хоть и с одной грядки, да неодинаково сладки (Onions and carrots are unequally sweet, although from the same garden)); 胡萝卜加大棒 (Carrot plus a club (about the simultaneous use of rewards and punishment for motivation)).

Consequently, the use of the cultivated plant component in the Russian and Chinese languages is very different, which is associated with the difference in the cultural characteristics of the life of peoples.

\subsection{Proverbs with the Component Uncultivated (Wild) Plant}

Among the phytonyms of this subgroup of proverbs, the component rose is often found in all languages. Since ancient times, among many peoples, the rose has been something beautiful, associated with blooming life and youth. On the one hand, the plant embodies an unapproachable beauty, and, on the other hand, a reward for labor, for example, this is evidenced by Russian proverbs «Без шипов розы не бывает» (Тhere is no rose without thorns), «Чем красивее роза, тем длиннее у нее шипы» (The more beautiful the rose, the longer its thorns).

In Chinese proverbs, the rose acquires an additional connotation - "behind something beautiful there are 
flaws": 玫瑰花可爱, 刺太扎手 (The rose flower is cute, but its thorns are extremely prickly (meaning "everything attractive has its drawbacks")).

However, the most common use for Chinese proverbs is the lotus plant, which can have different connotations:

1) causal relationship: 玫瑰花可爱，刺太扎手 (To pluck lotus flowers means to pull out its rhizome);

2) the relationship and interdependence of the phenomena: 藕断丝连 (The rhizome of the lotus is broken, but the fibers are stretching);

3) a description of a person who has achieved success by his work, despite a low social status: 莲花开在污 泥中, 人才出在贫寒家 (A lotus grows in the silt, talents come out of poor families) (The Great ChineseRussian Dictionary).

\section{CONCLUSIONS}

Plant names play an important role in Russian and Chinese proverbs. They serve as an object for evaluating a person, his appearance, moral qualities, behavior, and also characterize different aspects of a person's life. The vocabulary of the thematic group "plants" forms one of the significant fragments of the linguistic worldimage. This allows us to talk about the importance of the plant code in culture (Borisova, 2014, p. 44). The study of proverbs with the names of plants in the Russian and Chinese linguistic world-image is interesting and important in the linguoculturological aspect, since in these names we find many associative meanings that allow presenting better the peculiarities of mastering the world by means of the national language.

\section{REFERENCE LIST}

The Great Chinese-Russian Dictionary (1983).

Borisova, L. V. (2014) The concept "tree" as a linguocultural code. Bulletin of the Moscow State Humanitarian University named after M. A. Sholokhov. Philological Sciences, vol. 1.

Borisova, L. V., Ivanova, A. M. (2018) The "cultivated plants" cluster in the linguistic world image: Russian and Chuvash parallels. Moscow University Bulletin, 22 (vol. 3).

Dal, V. I. (1984) Proverbs of the Russian people.

Maslova, V. A. (2001) Linguoculturology.

Ozhegov, S. I. Explanatory Dictionary of the Russian Language. https://slovarozhegova.ru/

Xinhua Dictionary (2011).

Shvedova, N. Yu. (1999) Theoretical results obtained in the work on the "Russian Semantic Dictionary". Questions of linguistics. 